\title{
Modulation of the Proteasome Pathway by Nano-Curcumin and Curcumin in Retinal Pigment Epithelial Cells
}

\author{
J. Emanuel Ramos de Carvalho ${ }^{a}$ Milan T. Verwoert ${ }^{a} \quad$ Ilse M.C. Vogels ${ }^{a}$ \\ Sabine Schipper-Krom ${ }^{b}$ Cornelis J.F. Van Noorden ${ }^{a, b}$ Eric A. Reits ${ }^{b}$ \\ Ingeborg Klaassen ${ }^{\mathrm{a}}$ Reinier O. Schlingemann ${ }^{\mathrm{a}}$ \\ ${ }^{a}$ Ocular Angiogenesis Group, Department of Ophthalmology and ${ }^{b}$ Department of Medical Biology, \\ Academic Medical Center, University of Amsterdam, Amsterdam, The Netherlands
}

\author{
Keywords \\ Curcumin · Nano-curcumin · Proteasome $\cdot$ Retinal pigment \\ epithelium
}

\begin{abstract}
Introduction: Curcumin has multiple biological effects including the modulation of protein homeostasis by the ubiquitin-proteasome system. The purpose of this study was to assess the in vitro cytotoxic and oxidative effects of nanocurcumin and standard curcumin and characterize their effects on proteasome regulation in retinal pigment epithelial (RPE) cells. Methods: Viability, cell cycle progression, and reactive oxygen species (ROS) production were determined after treatment with nano-curcumin or curcumin. Subsequently, the effects of nano-curcumin and curcumin on proteasome activity and the gene and protein expression of proteasome subunits PA28a, $a_{7}, \beta_{5}$, and $\beta_{5 i}$ were assessed. Results: Nano-curcumin $(5-100 \mu \mathrm{M})$ did not show significant cytotoxicity or anti-oxidative effects against $\mathrm{H}_{2} \mathrm{O}_{2}$-induced oxidative stress, whereas curcumin $(\geq 10 \mu \mathrm{M})$ was cytotoxic and a potent inducer of ROS production. Both nano-curcum-
\end{abstract}

in and curcumin induced changes in proteasome-mediated proteolytic activity characterized by increased activity of the proteasome subunits $\beta_{2}$ and $\beta_{5 i} / \beta_{1}$ and reduced activity of $\beta_{5} / \beta_{1 i}$. Likewise, nano-curcumin and curcumin affected mRNA and protein levels of household and immunoproteasome subunits. Conclusions: Nano-curcumin is less toxic to RPE cells and less prone to induce ROS production than curcumin. Both nano-curcumin and curcumin increase proteasome-mediated proteolytic activity. These results suggest that nano-curcumin may be regarded as a proteasome-modulating agent of limited cytotoxicity for RPE cells.

(c) 2017 S. Karger AG, Basel

\section{Introduction}

Curcumin (1, 7-bis-[4-hydroxy-3-methoxyphenyl]-1, 6-heptadiene-3,5-dione) is the orange and water-insoluble pigment extract of turmeric, the rhizome of Curcuma longa. The therapeutic potential of curcumin is currently being tested in several clinical trials after promising preliminary observations [1]. In ophthalmology, curcumin

\section{KARGER}

(C) 2017 S. Karger AG, Basel

E-Mail karger@karger.com

www.karger.com/ore
J.E. Ramos de Carvalho

Ocular Angiogenesis Group, Department of Ophthalmology

Academic Medical Center, PO Box 22660

NL-1100 DD Amsterdam (The Netherlands)

E-Mail j.e.decarvalho@amc.uva.nl 
has been proposed as a potential therapeutic agent for several conditions including dry eye syndrome [2], diabetic retinopathy $[3,4]$, diabetic retinal neurodegeneration [5], age-related macular degeneration (AMD) [6], retinitis pigmentosa $[7,8]$, and light- and oxidative stressinduced retinal neurodegeneration [9]. On the other hand, studies have warned of the potential toxic effects of curcumin in retinal pigment epithelial (RPE) cells [1012] and retinal endothelial cells [13].

One of the major obstacles precluding the implementation of curcumin as a therapeutic agent lies in its poor bioavailability in organs and tissues other than the gastrointestinal tract when given orally [14]. At present, various curcumin formulations with improved bioavailability, including nano-particles as drug delivery systems, are being assessed [15]. However, these different formulations do not have comparable biological properties [16]. Recently, a highly absorptive curcumin dispersed with polysaccharide nano-particles (Theracurmin ${ }^{\circledR}$ or nano-curcumin) has been developed. The oral absorption efficacy of nano-curcumin is approximately 40 -fold greater than that of curcumin in both rats and humans [17], which implies that this specific formulation is taken up by the epithelial cells of the gastrointestinal tract and reaches blood levels that are deemed sufficient for bioactivity [18, 19].

The ubiquitin-proteasome system (UPS), a multi-catalytic cytoplasmic and nuclear protein complex present in all eukaryotic cells, is responsible for non-lysosomal proteolysis [20]. Intracellular proteins are tagged for proteolysis after binding of ubiquitin moieties. These are then recognized by the $19 \mathrm{~S}$ regulatory particle of the proteasome, which, in combination with the $20 \mathrm{~S}$ catalytic core, forms the household or "classical" proteasome [21]. Within the proteasome core, 3 different specialized catalytic subunits are responsible for proteolytic cleavage of the carboxyl end of proteins: $\beta_{1}$ for acidic amino acids (caspase-like), $\beta_{2}$ for basic amino acids (trypsin-like), and $\beta_{5}$ for hydrophobic amino acids (chymotrypsin-like). In response to stress and injury, the household proteasome changes its configuration into the so-called immunoproteasome, which is formed upon replacement of the constitutive subunits by the inducible subunits, $\beta_{1 \mathrm{i}}, \beta_{2 \mathrm{i}}$, and $\beta_{5 \mathrm{i}}[22,23]$. Therefore, the ratio between the household $\left(\beta_{1}, \beta_{2}\right.$, and $\left.\beta_{5}\right)$ and inducible subunits $\left(\beta_{1 \mathrm{i}}, \beta_{2 \mathrm{i}}\right.$, and $\left.\beta_{5 \mathrm{i}}\right)$ is a marker of cellular stress [24-26].

Curcumin has been show to modulate proteasome function by different mechanisms. First, the carbonyl carbons of curcumin interact with the hydroxyl group of the amino-terminal threonine residue of the $\beta 5$ subunit; this results in the suppression of the protease activity of the proteasome, and particularly that of the chymotrypsinlike $\left(\beta_{5}\right)$ subunit [27]. Second, curcumin inhibits COP9 signalosome (CSN) kinase activity $[28,29]$. CSN is a protein complex that controls the stability of many proteins such as ligases [30], and it possesses structural similarities to multiple non-ATPase subunits of the $19 \mathrm{~S}$ lid of the proteasome [31]. The ligases interact with specific ubiquitinconjugating enzymes in the ubiquitination of substrates, and, as such, CSN functions as an interface between signal transduction and ubiquitin-dependent proteolysis [32]. Third, curcumin has been shown to inhibit ubiquitin isopeptidases, a family of cysteine proteases (deubiquitinases) responsible for the reutilization of ubiquitin by the $26 \mathrm{~S}$ proteasome $[27,33,34]$. Curcumin contains an $\alpha, \beta$ unsaturated ketone and 2 sterically accessible $\beta$-carbons that mediate inhibition of these enzymes [31].

A steadily increasing number of clinical trials are investigating the potential therapeutic effects of curcumin and other curcuminoid formulations. However, recent reports of curcumin-mediated retinal cytotoxicity [1013] could imply that chronic intake of curcumin negatively affects retinal function. The aims of this study are the following: (1) to assess and characterize the cytotoxic and oxidative effects of nano-curcumin and standard curcumin in RPE cells in vitro, and (2) to investigate the in vitro effects of nano-curcumin and standard curcumin on proteasome expression and activity in RPE cells, to ascertain whether they can be used as proteasome-modulating agents in retinal disorders.

\section{Methods}

Culture, Maintenance, and Treatment of ARPE-19 Cells

Experiments were conducted using ARPE-19 cells, a human RPE cell line with structural and functional properties that are characteristic of RPE cells in vivo. Cells were cultured at $37^{\circ} \mathrm{C}$ in $5 \% \mathrm{CO}_{2}$ in gelatin-coated T75 cell culture flasks (Corning, Lowell, MA, USA) in Dulbecco modified Eagle medium (DMEM; Gibco Life Technologies, Carlsbad, CA, USA), low glucose, pyruvate in the presence of $1 \%$ penicillin/streptomycin, and $10 \%$ fetal calf serum. Cell growth was monitored and the medium was changed twice a week. For the passaging of cells, TrypLE Express (Invitrogen, Carlsbad, CA, USA) was added for trypsinization of the cells and cell suspensions were diluted 3-fold. For experiments, cells were cultured in 6-well plates. Upon confluence, cells were washed once with phosphate-buffered saline (PBS), serum-starved for $24 \mathrm{~h}$, and then treated with different concentrations of nano-curcumin (Theracurmin, kindly provided by Dr. C. Tamura, Theravalues, Tokyo, Japan) and curcumin (kindly provided by Dr. E. Kemper, Academic Medical Center, Amsterdam, The Netherlands). Both the nano-curcumin and standard curcumin were dissolved in sterile water. 
Table 1. Primer details

\begin{tabular}{|c|c|c|c|c|c|}
\hline Gene & GenBank & Forward primer & Reverse primer & $\begin{array}{l}\text { Size, } \\
\text { bp }\end{array}$ & $\begin{array}{l}\text { Temperature, } \\
{ }^{\circ} \mathrm{C}\end{array}$ \\
\hline PSME1 & NM_006263 & CAGCCCCATGTGGGTGATTATC & GCTTCTCGAAGTTCTTCAGGATGAT & 139 & 82 \\
\hline PSMB5 & NM_002797 & CCATGATCTGTGGCTGGGATAAG & GGTCATAGGAATAGCCCCGATC & 144 & 83 \\
\hline PSMB8 & NM_004159 & CTGGAGGCGTTGTCAATATGTACC & GCAGCAGGTCACTGACATCTGTAC & 81 & 76 \\
\hline
\end{tabular}

Gene nomenclature, GenBank accession code, primer sequences, and the predicted size and temperature of the amplified product.

\section{Protein Extraction}

Cells were harvested using TrypLE Express (Invitrogen), collected in Eppendorf tubes and centrifuged for $10 \mathrm{~min}$ at $400 \mathrm{~g}$. Supernatant was removed and the pellet was suspended in TSDG buffer (10 mM Tris, pH 7.5, $25 \mathrm{~mm} \mathrm{KCl,} 10 \mathrm{mM} \mathrm{NaCl}, 1.1 \mathrm{~mm}$ $\mathrm{MgCl}_{2}, 0.1 \mathrm{mM}$ EDTA, and $8 \%$ glycerol), $5 \mathrm{~mm} \mathrm{ATP}$ and $1 \times$ protease inhibitor (Roche Applied Science, Penzberg, Germany).

Cells were lysed by 3 cycles of freezing in liquid nitrogen and thawing at room temperature. After centrifugation (15 min; $10,000 \mathrm{~g}$ ), protein concentrations were determined using a Bradford protein assay (Serva, Heidelberg, Germany).

\section{Cytoxicity Assays of ARPE-19 Cells Treated with Nano-}

\section{Curcumin or Curcumin}

To assess the viability of untreated ARPE-19 cells and the possible toxic effects of nano-curcumin and curcumin, the PrestoBlue cytotoxicity assay (Invitrogen) was performed according to the manufacturer's instructions. A resazurin-based compound is converted to its reduced form in the intact mitochondria of viable cells; this causes a shift in its color and fluorescence and can thus be quantified fluorometrically or spectrophotometrically. The assay was also used to test whether nano-curcumin or curcumin (concentrations of $20 \mu \mathrm{M}$ incubated for $3 \mathrm{~h}$ ) affect the cytotoxicity of $0-1,000 \mu \mathrm{M}$ hydrogen peroxide $\left(\mathrm{H}_{2} \mathrm{O}_{2}\right)$ in ARPE- 19 cells.

The assays were carried out in 96-well plates (10,000-25,000 cells per well). After cell adherence and subsequent washing, PrestoBlue reagent was added to each well. The plates were then incubated at $37^{\circ} \mathrm{C}$ for $20-30 \mathrm{~min}$. After incubation, the solution containing PrestoBlue was transferred from the wells of the assay plates to new wells in a 96-well plate, and absorbance was read on a plate reader (Bio-Rad, Hercules, CA, USA), with the excitation and emission wavelengths set at 570 and $600 \mathrm{~nm}$, respectively.

Cell Cycle Progression Analysis of ARPE-19 Cells Treated with

Nano-Curcumin or Curcumin

In order to evaluate the effects of nano-curcumin and curcumin on cell proliferation, the Click-iT EdU Alexa Fluor 488 imaging kit (Invitrogen) was applied according to the protocol provided by the manufacturer. Briefly, ARPE-19 cells at 30-50\% confluence were incubated for $24 \mathrm{~h}$ with EdU (5-ethynyl-2'-deoxyuridine). EdU, an analog of thymidine, is incorporated into newly synthesized DNA, and is subsequently recognized by azide dyes via a copper-mediated ("click") reaction. As a negative control, untreated cells were assessed and fluorescence per cell was detected using a FACS LSRII cell sorter (Becton Dickinson, Breda, The Netherlands).
Analysis of Reactive Oxygen Species Production of ARPE-19

Cells Treated with Nano-Curcumin or Curcumin

The production of reactive oxygen species (ROS) in ARPE-19 cells in the presence or absence of nano-curcumin or curcumin $(5$ or $50 \mu \mathrm{M}$ ) was determined by a FACS-based ROS detection kit (Enzo Life Sciences, Plymouth Meeting, PA, USA) using a modified protocol [35]. Untreated and unstained cells were used alongside a positive control with a ROS inducer ( $200 \mu \mathrm{M}$ pyocyanine) and a negative control with a ROS inhibitor (5 mM N-acetyl-Lcysteine). ARPE-19 cells incubated with nano-curcumin or curcumin were also treated with $250 \mu \mathrm{M} \mathrm{H}_{2} \mathrm{O}_{2}$. After staining for 30 min, fluorescence per cell in the green channel was detected using a FACS LSRII.

Measurement of Activity of Proteasome Subunit Complexes after Treatment of RPE Cells with Nano-Curcumin or Curcumin

We investigated the potential role of nano-curcumin and curcumin as proteasome-modulating agents in RPE cells. Proteasome catalytic subunits $\beta_{2}, \beta_{5 i} / \beta_{1}$, and $\beta_{5} / \beta_{1 \mathrm{i}}$ were labeled in lysates of ARPE- 19 cells treated with nano-curcumin or curcumin $(5,50$, or $100 \mu \mathrm{M})$ with a $0.5 \mu \mathrm{M}$ activity-based probe BODIPY-epoxomicin for $1 \mathrm{~h}$ at $37^{\circ} \mathrm{C}$ (BodipyFl-Ahx3L3VS, MV121, provided by Prof. Dr. H. Overkleeft, Institute of Chemistry, Leiden, The Netherlands) [36]. Sample buffer (350 mM Tris- $\mathrm{HCl}$ pH 6.8, 10\% SDS, $30 \%$ glycerol, $6 \% \beta$-mercaptoethanol, $0.02 \%$ bromophenol blue) was added to $20 \mu \mathrm{g}$ of protein lysate. The samples were boiled for 5 min and loaded on a $12.5 \%$ SDS-PAGE gel. After running the proteins on the gel, fluorescence imaging was performed using a Trio Typhoon (GE Medical Systems, Little Chalfont, UK) and a 580 bandpass filter to detect the probe directly on the gel. Proteasome total activity values were normalized on the basis of the total proteasome content in cells as indicated by the levels of the $\alpha_{7}$ subunit of the 20S proteasome (1:1,000; MCP72; Enzo Life Sciences).

Western Blot Analysis of Isolated RPE Proteasome Subunits after Treatment with Nano-Curcumin or Curcumin

Western blot analysis was performed as described previously [37]. After treatment with nano-curcumin or curcumin $(5,10,20$, or $50 \mu \mathrm{M}$ at $24 \mathrm{~h}$ and $50 \mu \mathrm{M}$ at $48 \mathrm{~h}$ ), $20 \mu \mathrm{g}$ of RPE cell protein was loaded on a $12.5 \%$ SDS-PAGE gel, and, after electrophoresis, was transferred to nitrocellulose membranes and semi-quantitatively analyzed. Membranes were incubated overnight or longer at $4^{\circ} \mathrm{C}$ in the presence of either a monoclonal antibody against the $\alpha_{7}$ subunit of the 20S proteasome (1:1,000; BML-PW8110-0025; Enzo Life Sciences) or one of the following polyclonal antibodies: 


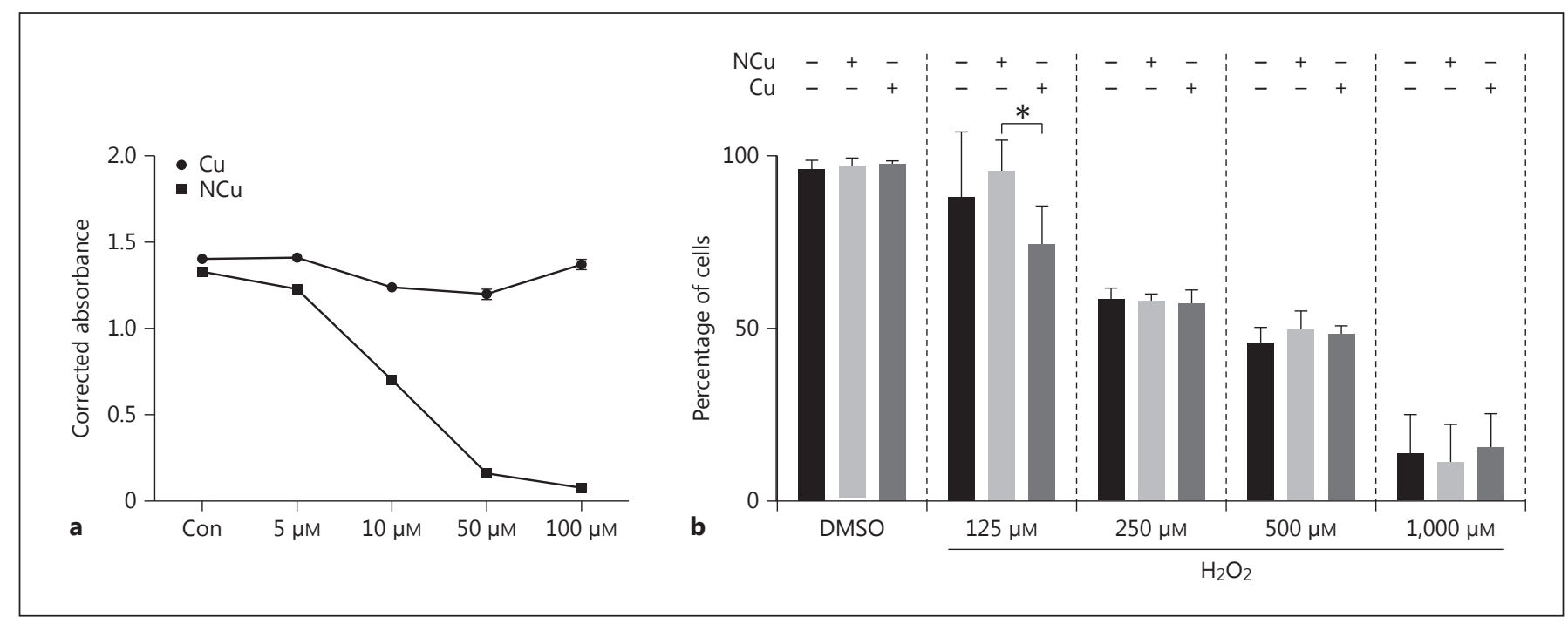

Fig. 1. Effects of nano-curcumin and curcumin on cell viability. Viability assays of ARPE-19 cells exposed to 0-100 $\mu \mathrm{M}$ of nanocurcumin $(\mathrm{NCu})$ or standard curcumin $(\mathrm{Cu})$ in the presence of $0-1,000 \mu \mathrm{M}$ of $\mathrm{H}_{2} \mathrm{O}_{2}$. a Concentration-dependent effects of nanocurcumin and curcumin on ARPE-19 cell viability expressed as corrected absorbance. b Cytotoxicity effects of $0-1,000 \mu \mathrm{M}$ of $\mathrm{H}_{2} \mathrm{O}_{2}$ on ARPE-19 cells, untreated and after pre-treatment with nanocurcumin or curcumin $(20 \mu \mathrm{M}$ for $3 \mathrm{~h})$ and expressed as mean percentage of viable cells \pm standard deviation (SD) when compared to untreated cells $(0.1 \% \mathrm{DMSO}) .{ }^{*} p<0.05$ significant change.

\section{Statistical Analysis}

Data is presented as fold-change, with a fold-change of 1.0 meaning the same level as control samples. Asterisks indicate a significant change relative to the control samples. Differences between experimental conditions were calculated with one-way or two-way ANOVA, with $p<0.05$ indicating a statistical difference. Statistical analysis of data was performed using IBM SPSS v20 (SPSS, Chicago, IL, USA).

\section{Results}

\section{Treatment with Nano-Curcumin or Curcumin}

RNA Isolation and Quantification of RPE $m R N A$ after

Real-time quantitative PCR experiments were performed to detect mRNA expression of the proteasome regulatory subunits, PA28a (PSME), $\alpha_{7}$ (PSMA7), $\beta_{5}$ (PSMB5), and $\beta_{5 \mathrm{i}}$ (PSMB8). Total RNA was isolated from ARPE-19 cell cultures (6 samples/experimental condition) according to the manufacturer's instructions (TRIzol; Invitrogen) after incubation with low $(10 \mu \mathrm{M})$ and high $(50 \mu \mathrm{M})$ concentrations of nano-curcumin and curcumin.

Total RNA $(1 \mu \mathrm{g})$ was treated with DNAse I (amplification grade; Life Technologies) and reverse-transcribed into firststrand cDNA using a Maxima ${ }^{\circledR}$ First Strand cDNA synthesis kit (Thermo Scientific, Roskilde, Denmark). Real-time qPCR was performed using a CFX96 system (Bio-Rad) as described previously [38]. Primer details are presented in Table 1. The specificity of the primers was confirmed by NCBI BLAST. The presence of a single PCR product was verified by both the presence of a single melting temperature peak and detection of a single band of the expected size on 3\% agarose gel. Non-template controls were included to verify the method and the specificity of the primers. Ct values were converted to arbitrary absolute amounts $\left(2^{-\mathrm{Ct}} \times 1 \mathrm{E}^{12}\right)$.

Proteasome Modulation by Nano-Curcumin in RPE Cells
Ophthalmic Res 2018;59:98-109

DOI: $10.1159 / 000481261$
Nano-Curcumin Is Not Cytotoxic for ARPE-19 Cells, unlike Curcumin, and Does Not Protect against

\section{Oxidative Stress-Mediated Cell Death}

We found no significant cytotoxicity in ARPE-19 cells exposed to 5-100 $\mu \mathrm{M}$ of nano-curcumin whereas exposure to $10-100 \mu \mathrm{M}$ curcumin induced significant cytotoxic effects (Fig. 1a). Hardly any viable cells were found after incubation in the presence of $50-100 \mu \mathrm{M}$ curcumin (Fig. 1a). Next, we assessed whether nano-curcumin or curcumin prevented cytotoxic effects of $125-1,000 \mu \mathrm{M}$ $\mathrm{H}_{2} \mathrm{O}_{2}$. The highest non-lethal concentration of curcumin $(20 \mu \mathrm{M})$ was selected, and compared to a similar concentration of nano-curcumin. As expected, exposure to $\mathrm{H}_{2} \mathrm{O}_{2}$ caused dose-dependent cytotoxicity in ARPE-19 cells (Fig. 1b). Pre-treatment with $20 \mu \mathrm{M}$ curcumin increased the cytotoxicity of RPE cells when exposed to $125 \mu \mathrm{M}$ 


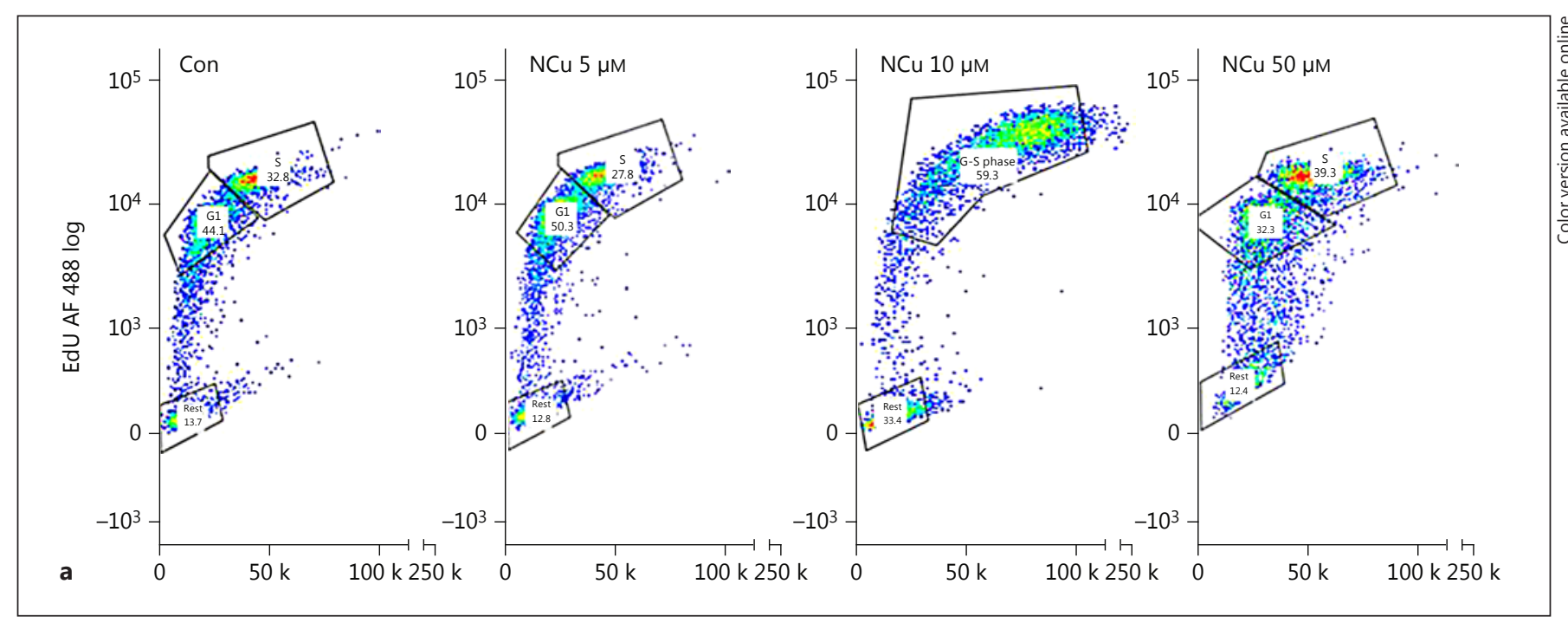

Fig. 2. Effects of nano-curcumin on cell proliferation. Cell proliferation assay of ARPE- 19 cells in the presence of $0-50 \mu \mathrm{M}$ of nanocurcumin $(\mathrm{NCu})$ expressed as percentage of cells in the G0, G1, and $\mathrm{S}$ phases after flow cytometric analysis of fluorescence of incorporated EdU. a Contour plot of cells treated with 0, 5, 10, and $50 \mu \mathrm{M}$ of nano-curcumin. b Percentages of cells in the different cell phases. Con, control (untreated). No significant differences were found.

$\mathrm{H}_{2} \mathrm{O}_{2}$, in contrast to nano-curcumin which showed a mild protective effect $(p=0.04)$. This effect subsided upon higher concentrations of $\mathrm{H}_{2} \mathrm{O}_{2}$ (Fig. 1b).

Curcumin $(15 \mu \mathrm{M})$ treatment of RPE cells was previously shown to arrest cell cycle progression with arrest in the G1 phase [12]. Cell cycle progression of ARPE-19 cells exposed to $0-50 \mu \mathrm{M}$ nano-curcumin did not show significant changes in cell proliferation (Fig. 2).

\section{Nano-Curcumin Is a Mild ROS Inducer and}

Curcumin Is a Potent ROS Inducer in ARPE-19 Cells

ROS cause damage to cells and the extracellular matrix [39]. Because of the high retinal consumption of oxygen, the retina may be particularly susceptible to oxidative damage. Accordingly, oxidative stress has been linked to several senile degenerative diseases of the retina, including AMD [40-42].

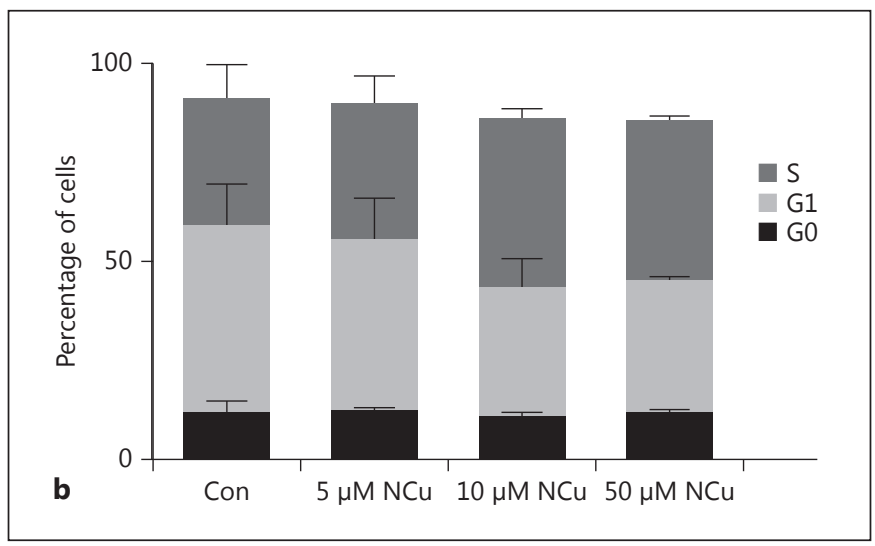

We determined the percentage of ROS-producing cells in the presence of 5 or $50 \mu \mathrm{M}$ of nano-curcumin or curcumin, and assessed whether the oxidative effects of nano-curcumin differed from those of standard curcumin. We demonstrated strong ROS-inducing effects in cells treated with both low and high concentrations of curcumin, comparable to the pro-oxidative effects of pyocyanin which was used as a positive control (Fig. 3). These effects may explain the dose-dependent cytotoxic effects of curcumin as shown in Figure 1. Low concentrations of nano-curcumin $(5 \mu \mathrm{M})$ did not induce significant ROS production, with ROS levels that were comparable to those obtained in unstained, untreated cells. High doses of nano-curcumin $(50 \mu \mathrm{M})$ induced significant ROS production. These results attribute significant pro-oxidative effects to curcumin, whereas low concentrations of nanocurcumin do not lead to significant ROS production in RPE cells. 


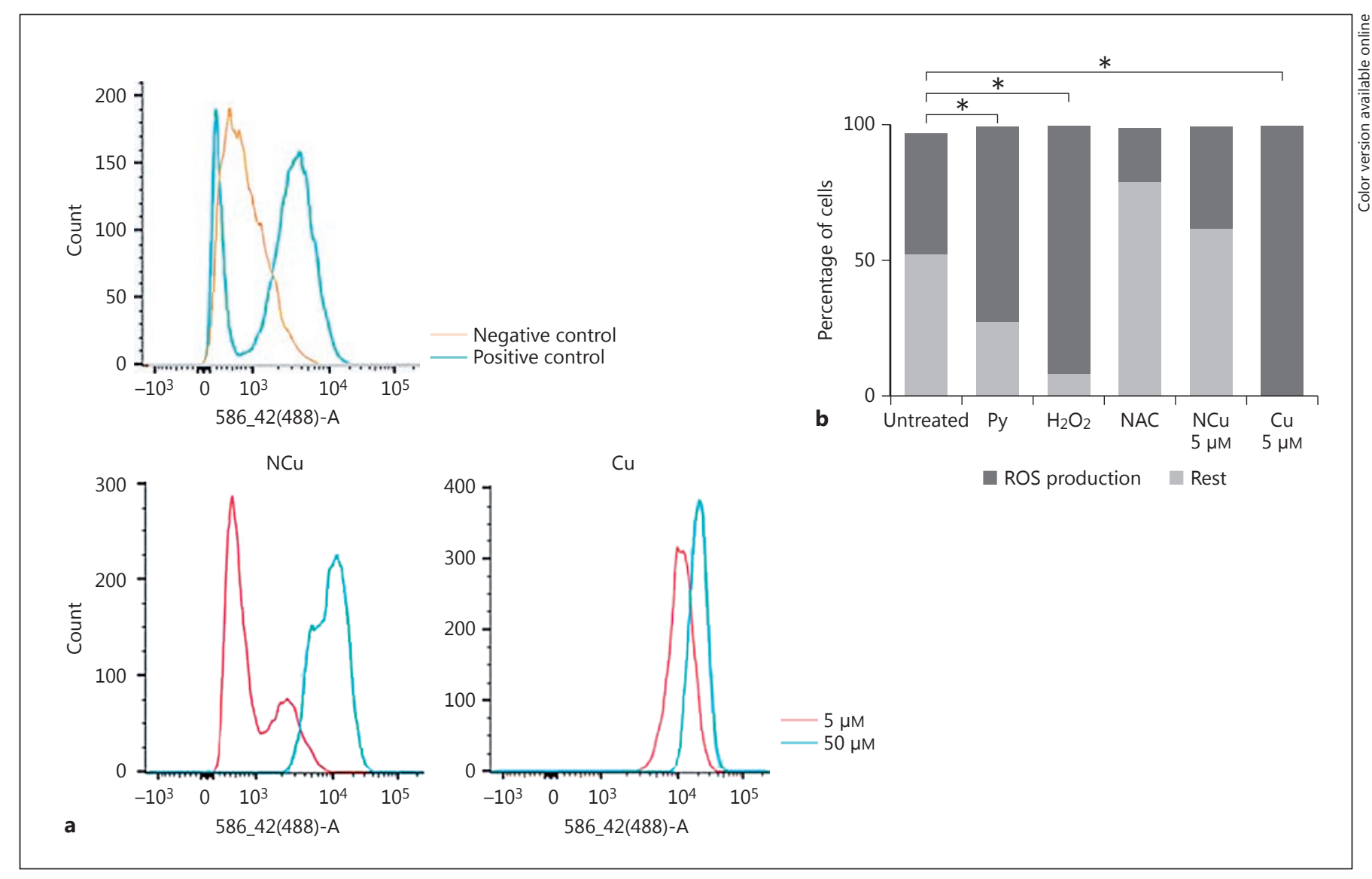

Fig. 3. Effects of nano-curcumin and curcumin on ROS production. Detection of ROS production in ARPE-19 cells treated with low $(5 \mu \mathrm{M})$ and high $(50 \mu \mathrm{M})$ concentrations of nano-curcumin $(\mathrm{NCu})$ or curcumin $(\mathrm{Cu})$. Cells were also treated with $200 \mu \mathrm{M}$ pyocyanin (general ROS inducer, positive control) and $5 \mathrm{mM}$ of $\mathrm{N}$ acetyl-L-cysteine (general ROS inhibitor, negative control). Cells were stained with ROS-ID ${ }^{\mathrm{TM}}$ total ROS detection reagent and analyzed using flow cytometry. Untreated cells were used as a control. Cell debris was ungated. The cells with increased levels of oxidative stress display bright green fluorescence in the presence of the ROS detection solution. a Histogram plots showing cells incubated in the presence of pyocyanin (positive control), N-acetyl-L-cysteine (negative control), nano-curcumin, and curcumin. Bright green fluorescence depicting increased ROS production (as observed in the positive control) is demonstrated in cells incubated with $50 \mu \mathrm{M}$ of nano-curcumin and 5 and $50 \mu \mathrm{M}$ of curcumin. b Percentage of cells actively producing ROS compared to untreated cells, incubated with pyocyanin, $\mathrm{H}_{2} \mathrm{O}_{2}, \mathrm{~N}$-acetyl-L-cysteine, nano-curcumin, and curcumin. All 3 independent experiments were carried out in triplicate. Py, pyocyanin; NAC, N-acetyl-L-cysteine; ROS reactive oxygen species. ${ }^{*} p<0.05$ significant change.
Nano-Curcumin and Curcumin Affect the Proteolytic Activity of the Proteasome Catalytic Subunits $\beta_{2}, \beta_{5 i}$ l $\beta_{1}$, and $\beta_{5} / \beta_{1 i}$

In order to assess whether nano-curcumin and curcumin affect the proteolytic activity of individual proteasome subunits, a proteasome activity-based probe assay was conducted. At present, available proteasome activity probes are unable to distinguish $\beta_{1}$ and $\beta_{5}$ from their inducible counterparts, $\beta_{1 \mathrm{i}}$ and $\beta_{5 \mathrm{i}}$, because the subunits run identically on gels (Fig. 4a). Nano-curcumin, at low concentrations $(5 \mu \mathrm{M})$, down-regulated the activity of the $\beta_{5} /$ $\beta_{1 \mathrm{i}}$ proteasome catalytic subunits ( 0.57 fold-change, $p=$ $0.0009)$. Intermediate $(10 \mu \mathrm{M})$ and high $(50 \mu \mathrm{M})$ concentrations of nano-curcumin up-regulated the activity of the $\beta_{2}$ (1.27 fold-change, $p=0.03$ and 1.55 fold-change, $p=$ 0.0005 , respectively) and $\beta_{5 i} / \beta_{1}$ proteasome catalytic subunits (1.46 fold-change, $p=0.01$ and 1.54 fold-change, $p=$ 0.04 , respectively). Intermediate $(10 \mu \mathrm{M})$ and high $(50 \mu \mathrm{M})$ concentrations of curcumin down-regulated the activity of the $\beta_{5} / \beta_{1 \mathrm{i}}$ proteasome catalytic subunits ( 0.89 fold-change, $p=0.009$ and 0.92 fold-change, $p=0.015$, respectively). Similar to the effects observed with nano-curcumin, high 
Fig. 4. Effects of nano-curcumin and curcumin on proteasome activity. Proteasome activity labelling in ARPE-19 cell lysates. a After treatment with $0-50 \mu \mathrm{M}$ of nanocurcumin $(\mathrm{NCu})$ or curcumin $(\mathrm{Cu}), \mathrm{ARPE}-$ 19 cells were harvested and proteasomes were labeled with a proteasome activity probe. Activity of the $\beta_{2}, \beta_{1} / \beta_{5 i}$, and $\beta_{5} / \beta_{1 i}$ proteasome catalytic subunits was determined by fluorescence imaging. $\mathbf{b}$ Data is expressed as mean proteolytic activity per subunit complex $\pm \mathrm{SD}$, normalized on the basis of the total proteasome content in cells as indicated by the levels of proteasome $\alpha_{7}$ subunit. ${ }^{*} p<0.05$ significant change; ${ }^{* *} p<0.01 ; * * * p<0.001$.

Fig. 5. Effects of nano-curcumin and curcumin on proteasome protein expression. Protein levels of proteasome subunits $\beta_{5}$, $\beta_{5 \mathrm{i}}$, and $\alpha_{7}$ were assessed by Western blot with actin expression as loading control after the incubation of ARPE-19 cells with $0-50 \mu \mathrm{M}$ of nano-curcumin $(\mathrm{NCu})$ and curcumin $(\mathrm{Cu})$ at $24 \mathrm{~h}\left(\beta_{5}, \beta_{5 \mathrm{i}}\right.$, and $\left.\alpha_{7}\right)$ and $48 \mathrm{~h}\left(\beta_{5}\right.$ and $\left.\beta_{5 \mathrm{i}}\right)$. a $\beta_{5 \mathrm{i}} / \beta_{5}$ ratio fold-change at $24 \mathrm{~h}$ induced by $0-50 \mu \mathrm{M}$ of nano-curcumin and curcumin, corrected for actin and relative to control samples. $\mathbf{b}$ Time-dependent effects in the $\beta_{5 i} / \beta_{5}$ ratio foldchange induced by nano-curcumin at 24 and $48 \mathrm{~h}$, corrected for actin and relative to control samples. c Protein levels of proteasome subunit $\alpha_{7}$ induced by $0-50 \mu \mathrm{M}$ of nano-curcumin and curcumin, corrected for actin and relative to control samples. Data is expressed as the mean $\pm \mathrm{SD} .{ }^{*} p<0.05$ significant change. a
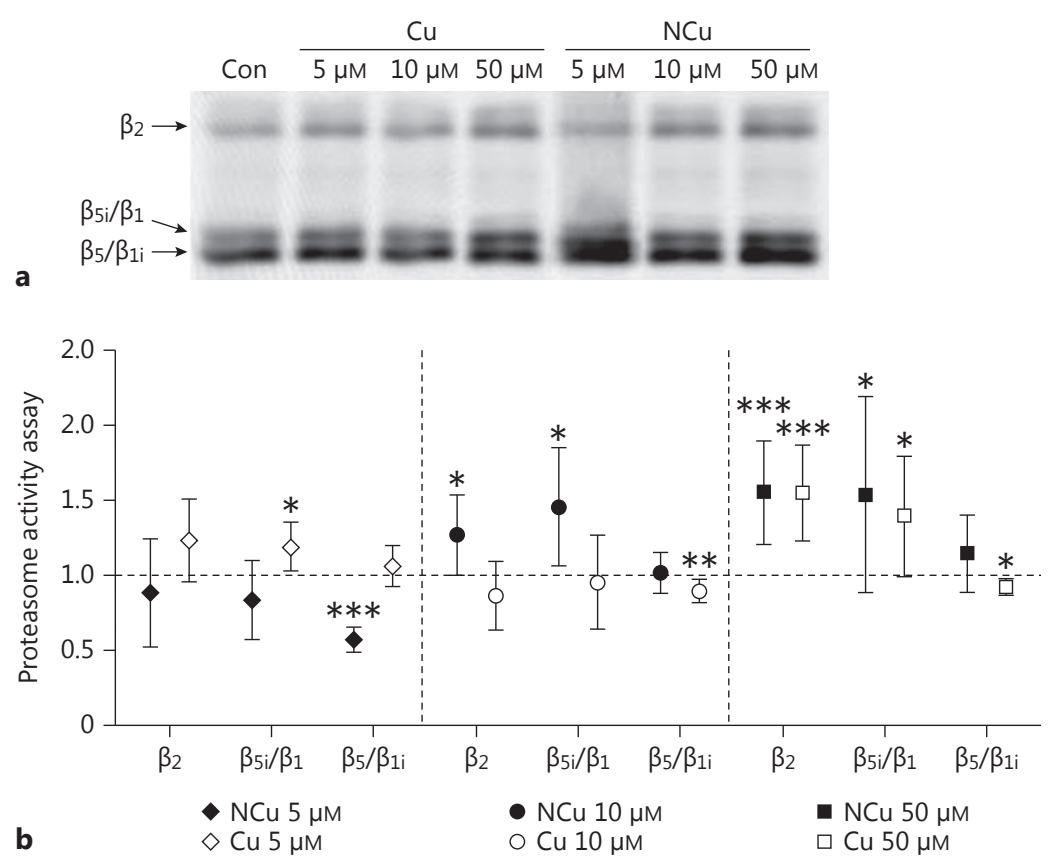
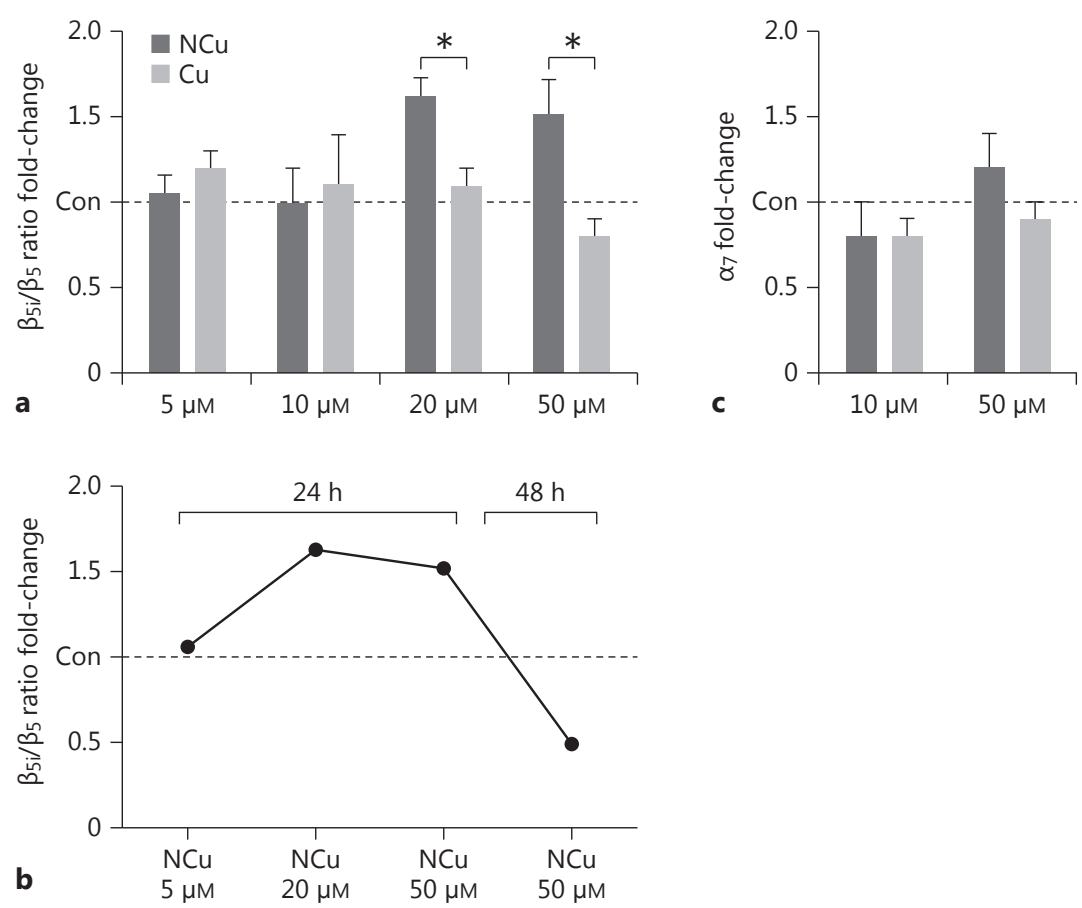


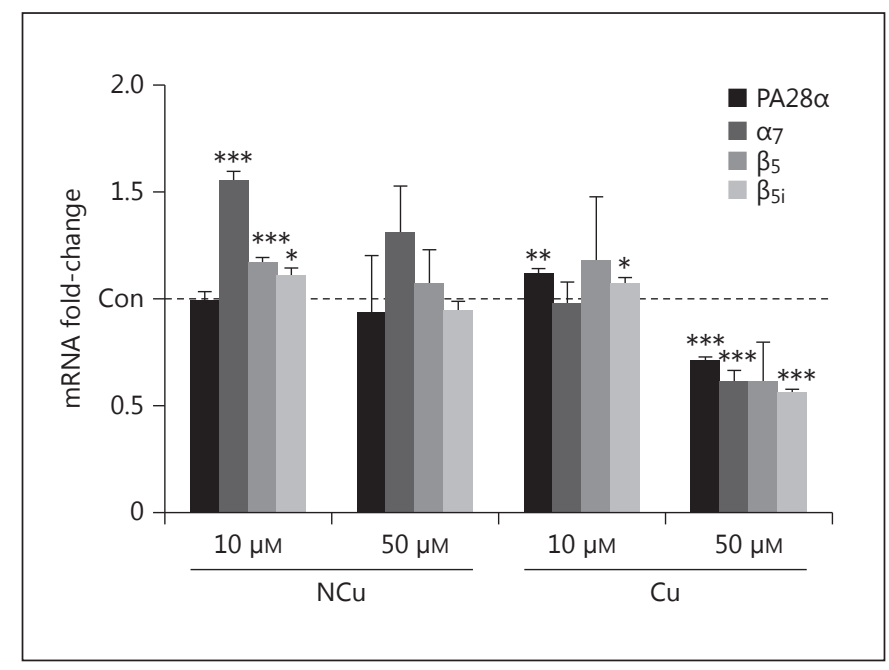

Fig. 6. Expression of proteasome-related genes after exposure to nano-curcumin and curcumin. mRNA levels of proteasome subunits PA28a, $\alpha_{7}, \beta_{5}$, and $\beta_{5 \mathrm{i}}$ after $72 \mathrm{~h}$ of treatment with nano-curcumin and curcumin $(0,10$, and $50 \mu \mathrm{M})$. The mRNA expression levels of $\alpha_{7}$ were increased upon stimulation with $10 \mu \mathrm{M}$ of nanocurcumin, and $\beta_{5}$ and $\beta_{5 \mathrm{i}}$ upon stimulation with 10 and $50 \mu \mathrm{M}$ of nano-curcumin. Treatment with $10 \mu \mathrm{M}$ of curcumin increased PA28 $\alpha$ and $\beta_{5 i}$ mRNA levels. Higher concentrations of curcumin $(50 \mu \mathrm{M})$ significantly decreased mRNA levels of PA28 $\alpha, \alpha_{7}$, and $\beta_{5 \mathrm{i}}$. Values represent mRNA expression levels \pm SD relative to untreated control cells. ${ }^{*} p<0.05$ significant change; ${ }^{* *} p<0.01$; ${ }^{* * *} p<$ 0.001 .

$(50 \mu \mathrm{M})$ concentrations of curcumin up-regulated the activity of the $\beta_{2}$ and $\beta_{5 i} / \beta_{1}$ proteasome catalytic subunits (1.55 fold-change, $p=0.002$ and 1.40 fold-change, $p=$ 0.035 , respectively) (Fig. $4 \mathrm{~b}$ ).These results suggest that nano-curcumin and curcumin have dose-dependent effects on proteasome-mediated proteolytic activity.

\section{Nano-Curcumin Induces a Mild Activation of the Immunoproteasome}

Protein levels of the proteasome subunits $\beta_{5}, \beta_{5 \mathrm{i}}$, and $\alpha_{7}$ were assessed after treatment with various concentrations of nano-curcumin and curcumin. The ratio between $\beta_{5 i}$ and $\beta_{5}$ was calculated at 2 time points as a marker of immunoproteasome activation. Protein levels of the $\alpha_{7}$ subunit of the $20 \mathrm{~S}$ proteasome depict the total pool of proteasomes in cells. Nano-curcumin $(50$ and $20 \mu \mathrm{M})$ increased the protein levels of proteasome subunit $\beta_{5 \mathrm{i}}$ (mean 1.6 fold-change, $p=0.01$, data not shown), resulting in an increased $\beta_{5 i} / \beta_{5}$ ratio when compared to the unstimulated and curcumin-treated RPE cells (Fig. 5a). This effect was both concentration- and time-dependent, as shown in Figure $5 \mathrm{~b}$ which demonstrates that, at $48 \mathrm{~h}$, the increase in $\beta 5 \mathrm{i} / \beta 5$ ratio was overturned. Neither nano-curcumin nor curcumin had a significant effect on the protein levels of the proteasome $\alpha_{7}$ subunit (Fig. $5 \mathrm{c}$ ). These results suggest that nano-curcumin may induce a mild activation of the immunoproteasome.

\section{Nano-Curcumin and Curcumin Affect the}

\section{Transcription of Proteasome-Related Genes}

In order to assess whether nano-curcumin affected the transcription of proteasome-related genes, qPCR of ARPE- 19 cells treated for $72 \mathrm{~h}$ with 10 and $50 \mu \mathrm{M}$ of nanocurcumin and curcumin was performed. Figure 6 shows that $10 \mu \mathrm{M}$ nano-curcumin increased the gene expression of the proteasome $\alpha_{7}$ subunit ( 1.56 fold-change, $p=0.03$ ), the $\beta_{5}$ subunit (1.18 fold-change, $\left.p=0.004\right)$, and the $\beta_{5 \mathrm{i}}$ subunit (1.11 fold-change, $p=0.04)$. Curcumin $(10 \mu \mathrm{M})$ increased the gene expression of the proteasome PA28a subunit (1.12 fold-change, $p=0.01$ ), and the $\beta_{5 \mathrm{i}}$ subunit (1.10 fold-change, $p=0.04$ ). Higher concentrations of curcumin $(50 \mu \mathrm{M})$ strongly reduced the gene expression of all proteasome-related genes $(p<0.001)$. These results show that nano-curcumin and curcumin have concentration-dependent effects on the transcription of proteasome-related genes.

\section{Discussion}

The results of this study support the pleiotropic properties of curcumin and its various formulations. A consensus regarding the effects of curcumin in the retina is yet to be reached. In this study, it was demonstrated that nano-curcumin induces changes in proteasome modulation with limited cytotoxic effects at low concentrations, suggesting that this specific formulation is a safe alternative for the retina and RPE. While some studies praise the beneficial effects of curcumin and its potential use in ophthalmic disease, others advocate that retinal function ought to be monitored during the intake of curcumin. Such contradictory findings may be explained by the hormetic properties attributed to curcumin, i.e., it is toxic at high doses but is able to exert adaptive stress responses at low doses $[43,44]$. In addition, certain biological effects of curcuminoids may depend on the specific formulation of curcumin used $[16,45]$. For instance, the number of methoxy groups dictates the anti-oxidative potency of curcumin [46] whereas the presence of phospholipids in curcumin formulations affects its biological activity [47]. Therefore, the use of different curcuminoid formulations may lead to contradictory results. 
Our study demonstrates significant cytotoxic effects of standard curcumin in RPE cells at concentrations $>20$ $\mu \mathrm{M}$. These findings are in agreement with the data of previous studies in which curcumin exhibited pro-apoptotic effects in RPE cells at concentrations of approximately 20 $\mu \mathrm{M}[10,11]$. These concentrations are in the same concentration range that is supposed to be effective in cancer cells [48-52]. On the other hand, nano-curcumin, a formulation of curcumin dispersed with polysaccharide nano-particles, showed no major cytotoxicity in RPE cells. The different cytotoxicity of these 2 formulations may be explained by the smaller size and increased solubility of nano-curcumin compared to curcumin. Curcumin, hardly soluble in water, forms particles that are $>20 \mu \mathrm{M}$ in diameter in aqueous solutions whereas the average diameter of nano-curcumin in aqueous solutions is 100 times smaller $(0.2 \mu \mathrm{M})$ [17]. Furthermore, nano-curcumin is more stable due to the formation of an amorphous state upon hydrogen bonding [53]. This suggests that monitoring of retinal toxicity is not required during concomitant intake of nano-curcumin; this may not hold true for standard curcumin.

The uptake of nano-curcumin in RPE cells was not investigated in this study. However, other studies provide evidence that RPE cells, similar to other cell lines, take up nano-curcumin. The epithelial cells of the gastrointestinal tract of rats and humans in vivo absorb nano-curcumin over 40 times more efficiently than standard curcumin $[17,18]$, and nano-curcumin has been shown to be taken up by oesophageal cancer cells and non-cancer cells in vitro [19].

Our findings suggest that curcumin-mediated cytotoxicity may be partly caused by increased ROS production. In contrast to curcumin, low concentrations of nano-curcumin $(5 \mu \mathrm{M})$ do not induce ROS production in non-oxidative conditions and have significantly fewer pro-oxidative effects when compared to curcumin. Higher concentrations of nano-curcumin, however, significantly induce ROS production. These results are in agreement with data from previous studies with other cell lines, in which curcumin was shown to possess rapid ROS-inducing effects [54-56]. In contrast, other in vitro ARPE19 cell studies attribute anti-oxidative properties to curcumin in aging and $\mathrm{H}_{2} \mathrm{O}_{2}$-mediated oxidative stress [57, 58]. According to our findings, and taking into account both the conflicting and supportive results reported in other studies, it appears that curcumin exhibits both proand anti-oxidative properties. Differences in experimental set-up, with regard to concentrations and stimulation times, may partly explain the contradictory findings.
Recent evidence shows that dysfunction of the UPS may contribute to the pathogenesis of several eye diseases $[24,26,59-65]$. Modulation of this pathway remains, however, an unexplored therapeutic target in retinal degenerative diseases. Curcumin has been reported to affect proteasome activity and expression in a biphasic, dosedependent manner [31]. Low concentrations of curcumin were found to up-regulate proteasome activity but high concentrations inhibited proteasome activity [31]. Chymotrypsin-like activity was increased by $46 \%$ after treatment of human keratinocytes with curcumin (up to $1 \mu \mathrm{M}$ for $24 \mathrm{~h}$ ) whereas higher concentrations of curcumin were inhibitory. At $10 \mu \mathrm{M}$, proteasome activity decreased to $46 \%$ of its initial value [66]. A possible explanation for this biphasic mechanism could be the fact that curcumin is both pro-oxidative and anti-oxidative. Mild or transient oxidative stress up-regulates proteasome activity and transiently enhances intracellular proteolysis whereas severe or continuous oxidative stress impairs proteasome function and decreases intracellular proteolysis [67].

Our study demonstrates that both nano-curcumin and curcumin exert concentration-dependent changes in the activity of proteasome individual subunits in RPE in vitro. A recently developed activity-based probe assay was used instead of the more commonly used ubiquitin-independent fluorogenic peptides and ubiquitin-dependent fluorescent reporters. Activity-based probes can detect alterations in proteasomal activity in gels, and can also be applied to visualize active proteasomes in living cells [6870]. Unlike fluorescence-labelled tags, activity-based probes label only completely assembled and active proteasome complexes, which may explain why the results obtained by these 2 different methods are not comparable and at times inconsistent. Overall, the activity of the $\beta_{2}$ and $\beta_{5 i} / \beta_{1}$ proteasome catalytic subunits is up-regulated with increasing concentrations of nano-curcumin and curcumin, whilst the activity of the $\beta_{5} / \beta_{1 \mathrm{i}}$ proteasome catalytic subunits is down-regulated after the treatment of RPE cells with both nano-curcumin and curcumin. Shortterm treatment of cells with high concentrations of both nano-curcumin and curcumin induced the expression of $\beta_{5 i}$ subunits, which translated in a higher number of $\beta_{5 i}$ subunits than $\beta_{5}$ subunits, i.e., the household proteasome underwent a change in configuration upon activation of the immunoproteasome. This effect cannot be explained by an increase in the number of proteasomes as the protein expression levels of the $\alpha_{7}$ subunit remained unchanged after nano-curcumin and curcumin treatment. The pool of proteasome subunits was replenished after 
treatment with low concentrations of nano-curcumin, as demonstrated by the increased mRNA expression of the $\alpha_{7}, \beta_{5}$, and $\beta_{5 \mathrm{i}}$ proteasome subunits. Of note, the effects on mRNA expression observed after treatment with $50 \mu \mathrm{M}$ curcumin, namely the down-regulation of the transcription of all proteasome-related genes, possibly reflects the potent cytotoxic effects at similar concentrations.

The pro-oxidative state induced by high concentrations of nano-curcumin and curcumin may explain the changes found in proteasome activity, and gene and protein expression. Indeed, oxidative stress has been shown to affect proteasome function [71, 72]. Notably, in the $\mathrm{RPE}$, the activity of $\beta_{5}$ is the rate-limiting step of proteasome activity $[20,27,65]$. Changes due to nano-curcumin treatment approximate those in other conditions that have been shown to be associated with $\beta_{5}$ proteasome activity inhibition, namely, aging [63] and complement overactivation [73]. Changes in the ratio between the immunoproteasome and the classic proteasome are indicative of cellular stress, inflammation, and oxidative stress $[24-26,60,73]$. It has been suggested that a continuous expression of the immunoproteasome in the retina is protective against neuronal stress and promotes repair mechanisms [24]. A possible mechanism for the inactivation of the $\beta_{5}$ subunit lies in the chemical structure of curcumin, via inhibition of the ubiquitin isopeptidase activity located at the $19 S$ regulatory subunit of the $26 \mathrm{~S}$ proteasome. Curcumin belongs to a class of compounds with $\alpha, \beta$ unsaturated ketones and 2 sterically accessible $\beta$-carbons [33]. Furthermore, curcumin has been shown to bind directly to the 20 S proteasome [27]. A recent study has confirmed that both carbonyl groups of curcumin are indeed susceptible to nucleophilic attack by $\mathrm{N}$-terminal threonine of the $\beta_{5}$ chymotrypsin-like subunit of the proteasome, thereby inhibiting its proteolytic activity [27].

The formulation of curcumin, the duration of culture, and the concentration used may account for the contra- dictory results described hitherto in several studies. It appears that the cytotoxic profile of each formulation of curcumin depends on its bioavailability, absorption, and cellular uptake. Further in vivo studies are required to assess the molecular effects of supplementation of curcumin in relation to retinal function. It is not known whether systemic administration of curcumin reaches the RPE and the neurosensory retina at concentrations capable of inducing significant molecular effects. If so, our findings suggest that curcumin may promote the development of RPE and retinal dysfunction which, in turn, can accelerate development of age-related retinal diseases. On the other hand, our results show that 2 different formulations of curcumin produce different biological effects. Nanocurcumin may be a safer alternative in clinical trials in the future. Finally, our results attribute significant proteasome-modulating properties to both nano-curcumin and curcumin. The changes in proteasome activity incurred after nano-curcumin treatment are characterized by an activation of the immunoproteasome, with consequent changes in the protein and gene expression of proteasome-related subunits.

\section{Acknowledgments}

This study was supported by grants from the Landelijke Stichting voor Blinden en Slechtzienden (LSBS), Stichting Blindenpenning, and MaculaFonds that contributed through UitZicht (Grant UitZicht 2011-15) and Stichting Oogfonds. The founding organizations had no participation in designing or conducting this study, data collection, management, analysis, interpretation, preparation, or review or approval of the manuscript.

\section{Disclosure Statement}

The authors declare that they have no conflict of interest.

\section{References}

Proteasome Modulation by Nano-Curcumin in RPE Cells
1 Park W, Amin AR, Chen ZG, Shin DM: New perspectives of curcumin in cancer prevention. Cancer Prev Res (Phila) 2013;6:387-400.

2 Chen M, Hu DN, Pan Z, Lu CW, Xue CY, Aass I: Curcumin protects against hyperosmoticity-induced IL-1 beta elevation in human corneal epithelial cell via MAPK pathways. Exp Eye Res 2010;90:437-443.

3 Sulaiman RS, Basavarajappa HD, Corson TW: Natural product inhibitors of ocular angiogenesis. Exp Eye Res 2014;129:161-171.
4 Gupta SK, Kumar B, Nag TC, Agrawal SS Agrawal R, Agrawal P, Saxena R, Srivastava S: Curcumin prevents experimental diabetic retinopathy in rats through its hypoglycemic, antioxidant, and anti-inflammatory mechanisms. J Ocul Pharmacol Ther 2011;27:123130.

5 Li J, Wang PP, Zhu YX, Chen Z, Shi TY, Lei WS, Yu SP: Curcumin inhibits neuronal loss in the retina and elevates $\mathrm{Ca} 2+/$ calmodulindependent protein kinase II activity in diabetic rats. J Ocul Pharmacol Ther 2015;31:555562. 
6 Li Y, Zou X, Cao K, Xu J, Yue TT, Dai F, Zhou B, Lu WY, Feng ZH, Liu JK: Curcumin analog 1, 5-bis (2-trifluoromethylphenyl)-1, 4-pentadien-3-one exhibits enhanced ability on Nrf2 activation and protection against acrolein-induced ARPE-19 cell toxicity. Toxicol Appl Pharm 2013;272:726-735.

7 Scott PA, Kaplan HJ, McCall MA: Prenatal exposure to curcumin protects rod photoreceptors in a transgenic Pro23His swine model of retinitis pigmentosa. Transl Vis Sci Technol 2015;4:5.

8 Vasireddy V, Chavali VRM, Joseph VT, Kadam R, Lin JH, Jamison JA, Kompella UB, Reddy GB, Ayyagari R: Rescue of photoreceptor degeneration by curcumin in transgenic rats with $\mathrm{P} 23 \mathrm{H}$ rhodopsin mutation. PLoS One 2011;6:e21193.

9 Mandal MNA, Patlolla JMR, Zheng L, Agbaga MP, Tran JTA, Wicker L, Asus-Jacobi A, Elliott MH, Rao CV, Anderson RE: Curcumin protects retinal cells from light-and oxidant stress-induced cell death. Free Rad Biol Med 2009;46:672-679.

10 Hollborn M, Chen R, Wiedemann P, Reichenbach A, Bringmann A, Kohen L: Cytotoxic effects of curcumin in human retinal pigment epithelial cells. PLoS One 2013;8:e59603.

11 Alex AF, Spitznas M, Tittel AP, Kurts C, Eter $\mathrm{N}$ : Inhibitory effect of epigallocatechin gallate (EGCG), resveratrol, and curcumin on proliferation of human retinal pigment epithelial cells in vitro. Cur Eye Res 2010;35:1021-1033.

12 Sun Y, You ZP: Curcumin inhibits human retinal pigment epithelial cell proliferation. Int J Mol Med 2014;34:1013-1019.

13 Premanand C, Rema M, Sameer MZ, Sujatha M, Balasubramanyam M: Effect of curcumin on proliferation of human retinal endothelial cells under in vitro conditions. Invest Ophthalmol Vis Sci 2006;47:2179-2184.

14 Anand P, Kunnumakkara AB, Newman RA, Aggarwal BB: Bioavailability of curcumin: problems and promises. Mol Pharmac 2007; 4:807-818.

15 Vyas A, Dandawate P, Padhye S, Ahmad A, Sarkar F: Perspectives on new synthetic curcumin analogs and their potential anticancer properties. Curr Pharm Design 2013;19: 2047-2069.

16 Mujtaba T, Kanwar J, Wan SB, Chan TH, Dou QP: Sensitizing human multiple myeloma cells to the proteasome inhibitor bortezomib by novel curcumin analogs. Int $\mathrm{J}$ Mol Med 2012;29:102-106.

17 Sasaki H, Sunagawa Y, Takahashi K, Imaizumi A, Fukuda H, Hashimoto T, Wada H, Katanasaka Y, Kakeya H, Fujita M, Hasegawa K, Morimoto T: Innovative preparation of curcumin for improved oral bioavailability. Biol Pharm Bull 2011;34:660-665.

18 Morimoto T, Sunagawa Y, Katanasaka Y, Hirano $S$, Namiki $M$, Watanabe $Y$, et al: Drinkable preparation of theracurmin exhibits high absorption efficiency: a single-dose, doubleblind, 4-way crossover study. Biol Pharm Bull 2013;36:1708-1714.
19 Milano F, Mari L, van de Luijtgaarden W, Parikh K, Calpe S, Krishnadath KK: Nanocurcumin inhibits proliferation of esophageal adenocarcinoma cells and enhances the $\mathrm{T}$ cell-mediated immune response. Front Oncol 2013;3:137.

20 Coux O, Tanaka K, Goldberg AL: Structure and functions of the $20 \mathrm{~S}$ and $26 \mathrm{~S}$ proteasomes. Ann Rev Biochem 1996;65:801-847.

21 Reits EAJ, Benham AM, Plougastel B, Neefjes J, Trowsdale J: Dynamics of proteasome distribution in living cells. EMBO J 1997;16: 6087-6094.

22 Dahlmann B, Ruppert T, Kuehn L, Merforth S, Kloetzel PM: Different proteasome subtypes in a single tissue exhibit different enzymatic properties. J Mol Biol 2000;303:643653.

23 Klare N, Seeger M, Janek K, Jungblut PR, Dahlmann B: Intermediate-type $20 \mathrm{~S}$ proteasomes in HeLa cells: "Asymmetric" subunit composition, diversity and adaptation. J Mol Biol 2007;373:1-10.

24 Ferrington DA, Hussong SA, Roehrich H, Kapphahn RJ, Kavanaugh SM, Heuss ND, Gregerson DS: Immunoproteasome responds to injury in the retina and brain. J Neurochem 2008;106:158-169.

25 Hussong SA, Kapphahn RJ, Phillips SL, Maldonado $M$, Ferrington DA: Immunoproteasome deficiency alters retinal proteasome's response to stress. J Neurochem 2010;113: 1481-1490.

26 Hussong SA, Roehrich H, Kapphahn RJ, Maldonado M, Pardue MT, Ferrington DA: A novel role for the immunoproteasome in retinal function. Inves Ophthalmol Vis Sci 2011; 52:714-723

27 Milacic V, Banerjee S, Landis-Piwowar KR, Sarkar FH, Majumdar APN, Dou QP: Curcumin inhibits the proteasome activity in human colon cancer cells in vitro and in vivo. Cancer Res 2008;68:7283-7292.

28 Uhle S, Medalia O, Waldron R, Dumdey R, Henklein P, Bech-Otschir D, Huang X, Berse M, Sperling J, Schade R, Dubiel W: Protein kinase CK2 and protein kinase D are associated with the COP9 signalosome. EMBO J 2003;22:1302-1312.

29 Henke W, Ferrell K, Bech-Otschir D, Seeger M, Schade R, Jungblut P, Naumann M, Dubiel W: Comparison of human COP9 signalosome and 26S proteasome "lid." Mol Biol Rep 1999;26:29-34.

30 Seeger M, Kraft R, Ferrell K, Bech-Otschir D, Dumdey R, Schade R, Gordon C, Naumann M, Dubiel W: A novel protein complex involved in signal transduction possessing similarities to $26 \mathrm{~S}$ proteasome subunits. FASEB J 1998;12:469-478

31 Hasima N, Aggarwal BB: Targeting proteasomal pathways by dietary curcumin for cancer prevention and treatment. Curr Med Chem 2014;21:1583-1594.
32 Bech-Otschir D, Seeger M, Dubiel W: The COP9 signalosome: at the interface between signal transduction and ubiquitin-dependent proteolysis. J Cell Sci 2002;115:467-473.

33 Mullally JE, Fitzpatrick FA: Pharmacophore model for novel inhibitors of ubiquitin isopeptidases that induce p53-independent cell death. Mol Pharmacol 2002;62:351-358.

34 Gupta SC, Prasad S, Kim JH, Patchva S, Webb LJ, Priyadarsini IK, Aggarwal BB: Multitargeting by curcumin as revealed by molecular interaction studies. Nat Prod Rep 2011;28: 1937-1955.

35 Hafer K, Iwamoto KS, Schiestl RH: Refinement of the dichlorofluorescein assay for flow cytometric measurement of reactive oxygen species in irradiated and bystander cell populations. Radiat Res 2008;169:460-468.

36 Verdoes M, Florea BI, Menendez-Benito V, Maynard CJ, Witte MD, Van der Linden WA, et al: A fluorescent broad-spectrum proteasome inhibitor for labeling proteasomes in vitro and in vivo. Chem Biol 2006;13:1217-1226.

37 Sambrook J, Gething MJ: Protein structure chaperones, paperones. Nature 1989;342: 224-225.

38 Klaassen I, Hughes JM, Vogels IMC, Schalkwijk CG, Van Noorden CJF, Schlingemann RO: Altered expression of genes related to blood-retina barrier disruption in streptozotocin-induced diabetes. Exp Eye Res 2009; 89:4-15.

39 Beckman KB, Ames BN: The free radical theory of aging matures. Physiol Rev 1998;78: 547-581.

40 Beatty S, Koh H, Phil M, Henson D, Boulton $\mathrm{M}$ : The role of oxidative stress in the pathogenesis of age-related macular degeneration. Surv Ophthalmol 2000;45:115-134.

41 Yildirim Z, Ucgun NI, Yildirim F: The role of oxidative stress and antioxidants in the pathogenesis of age-related macular degeneration. Clinics (Sao Paulo) 2011;66:743-746

42 Drobek-Slowik M, Karczewicz D, Safranow $\mathrm{K}$ : The potential role of oxidative stress in the pathogenesis of the age-related macular degeneration (AMD). Postepy Hig Med Dosw (Online) 2007;61:28-37.

43 Mattson MP: Dietary factors, hormesis and health. Ageing Res Rev 2008;7:43-48.

44 Mattson MP, Cheng AW: Neurohormetic phytochemicals: low-dose toxins that induce adaptive neuronal stress responses. Trends Neurosci 2006;29:632-639.

45 Jager R, Lowery RP, Calvanese AV, Joy JM, Purpura M, Wilson JM: Comparative absorption of curcumin formulations. Nutr J 2014; $13: 11$

46 Jayaprakasha GK, Rao LJ, Sakariah KK: Antioxidant activities of curcumin, demethoxycurcumin and bisdemethoxycurcumin. Food Chem 2006;98:720-724.

47 Cuomo J, Appendino G, Dern AS, Schneider E, McKinnon TP, Brown MJ, Togni S, Dixon BM: Comparative absorption of a standardized curcuminoid mixture and its lecithin formulation. J Nat Prod 2011;74:664-669. 
48 Burgos-Moron E, Calderon-Montano JM, Salvador J, Robles A, Lopez-Lazaro M: The dark side of curcumin. Int J Cancer 2010;126: 1771-1775.

49 Puliyappadamba VT, Cheriyan VT, Thulasidasan AK, Bava SV, Vinod BS, Prabhu PR, Varghese R, Bevin A, Venugopal S, Anto RJ: Nicotine-induced survival signaling in lung cancer cells is dependent on their p53 status while its down-regulation by curcumin is independent. Mol Cancer 2010;9:220.

50 Saha A, Kuzuhara T, Echigo N, Fujii A, Suganuma M, Fujiki H: Apoptosis of human lung cancer cells by curcumin mediated through up-regulation of "growth arrest and DNA damage inducible genes 45 and 153.” Biol Pharm Bull 2010;33:1291-1299.

51 Mudduluru G, George-William JN, Muppala S, Asangani IA, Kumarswamy R, Nelson LD, Allgayer $\mathrm{H}$ : Curcumin regulates miR-21 expression and inhibits invasion and metastasis in colorectal cancer. Biosci Rep 2011;31:185197.

52 Singh M, Singh N: Curcumin counteracts the proliferative effect of estradiol and induces apoptosis in cervical cancer cells. Mol Cell Biochem 2011;347:1-11.

53 Wang $\mathrm{C}, \mathrm{Ma} \mathrm{C}$, Wu Z, Liang $\mathrm{H}$, Yan $\mathrm{P}$, Song J, Ma N, Zhao Q: Enhanced bioavailability and anticancer effect of curcumin-loaded electrospun nanofiber: in vitro and in vivo study. Nanoscale Res Lett 2015;10:439.

54 Thayyullathil F, Chathoth S, Hago A, Patel M, Galadari S: Rapid reactive oxygen species (ROS) generation induced by curcumin leads to caspase-dependent and -independent apoptosis in L929 cells. Free Radic Biol Med 2008;45:1403-1412.

55 Bhaumik S, Anjum R, Rangaraj N, Pardhasaradhi BV, Khar A: Curcumin mediated apoptosis in AK-5 tumor cells involves the production of reactive oxygen intermediates. FEBS Lett 1999;456:311-314.
56 Atsumi T, Tonosaki K, Fujisawa S: Comparative cytotoxicity and ROS generation by curcumin and tetrahydrocurcumin following visible-light irradiation or treatment with horseradish peroxidase. Anticancer Res 2007; 27:363-371

57 Zhu W, Wu Y, Meng YF, Wang JY, Xu M, Tao $\mathrm{JJ}, \mathrm{Lu} \mathrm{J}$ : Effect of curcumin on aging retinal pigment epithelial cells. Drug Des Devel Ther 2015;9:5337-5344.

58 Woo JM, Shin DY, Lee SJ, Joe Y, Zheng M, Yim JH, Callaway Z, Chung HT: Curcumin protects retinal pigment epithelial cells against oxidative stress via induction of heme oxygenase-1 expression and reduction of reactive oxygen. Mol Vis 2012;18:901-908.

59 Ding QX, Martin S, Dimayuga E, BruceKeller AJ, Keller JN: LMP2 knock-out mice have reduced proteasome activities and increased levels of oxidatively damaged proteins. Antiox Redox Signal 2006;8:130-135.

60 Ethen CM, Hussong SA, Reilly C, Feng X, Olsen TW, Ferrington DA: Transformation of the proteasome with age-related macular degeneration. FEBS Lett 2007;581:885-890.

61 Fernandes AF, Guo WM, Zhang XY, Gallagher M, Ivan M, Taylor A, Pereira P, Shang F: Proteasome-dependent regulation of signal transduction in retinal pigment epithelial cells. Exp Eye Res 2006;83:1472-1481.

62 Fernandes AF, Zhou JL, Zhang XY, Bian QN, Sparrow J, Taylor A, Pereira P, Shang F: Oxidative inactivation of the proteasome in retinal pigment epithelial cells - a potential link between oxidative stress and up-regulation of interleukin-8. J Biol Chem 2008;283:2074520753.

63 Kapphahn RJ, Bigelow EJ, Ferrington DA: Age-dependent inhibition of proteasome chymotrypsin-like activity in the retina. Exp Eye Res 2007;84:646-654.

64 Li Y, Wang YS, Shen XF, Hui YN, Han J, Zhao $\mathrm{W}$, Zhu J: Alterations of activity and intracellular distribution of the $20 \mathrm{~S}$ proteasome in ageing retinal pigment epithelial cells. Exp Gerontol 2008;43:1114-1122.
65 Louie JL, Kapphahn RJ, Ferrington DA: Proteasome function and protein oxidation in the aged retina. Exp Eye Res 2002;75:271-284.

66 Ali RE, Rattan SIS: Curcumin's biphasic hormetic response on proteasome activity and heat-shock protein synthesis in human keratinocytes. Ann NY Acad Sci 2006; 1067:394399.

67 Shang F, Taylor A: Ubiquitin-proteasome pathway and cellular responses to oxidative stress. Free Rad Biol Med 2011;51:5-16.

68 Li N, Kuo CL, Paniagua G, van den Elst H, Verdoes M, Willems LI, van der Linden WA, Ruben M, van Genderen E, Gubbens J, van Wezel GP, Overkleeft HS, Florea BI: Relative quantification of proteasome activity by activity-based protein profiling and LC-MS/ MS. Nat Protoc 2013;8:1155-1168.

69 Li N, Overkleeft HS, Florea BI: Activity-based protein profiling: an enabling technology in chemical biology research. Curr Opin Chem Biol 2012;16:227-233.

70 Liggett A, Crawford LJ, Walker B, Morris TC, Irvine $\mathrm{AE}$ : Methods for measuring proteasome activity: current limitations and future developments. Leuk Res 2010;34:1403-1409.

71 Ding QX, Keller JN: Proteasome inhibition in oxidative stress neurotoxicity: implications for heat shock proteins. J Neurochem 2001; 77:1010-1017.

72 Okada K, Wangpoengtrakul C, Osawa T, Toyokuni S, Tanaka K, Uchida K: 4-Hydroxy2-nonenal-mediated impairment of intracellular proteolysis during oxidative stress identification of proteasomes as target molecules. J Biol Chem 1999;274:23787-23793.

73 de Carvalho JER, Klaassen I, Vogels IMC Schipper-Krom S, Van Noorden CJF, Reits E, Gorgels TGMF, Bergen AAB, Schlingemann RO: Complement factor $\mathrm{C} 3$ a alters proteasome function in human RPE cells and in an animal model of age-related RPE degeneration. Inves Ophthalmol Vis Sci 2013;54:64896501. 